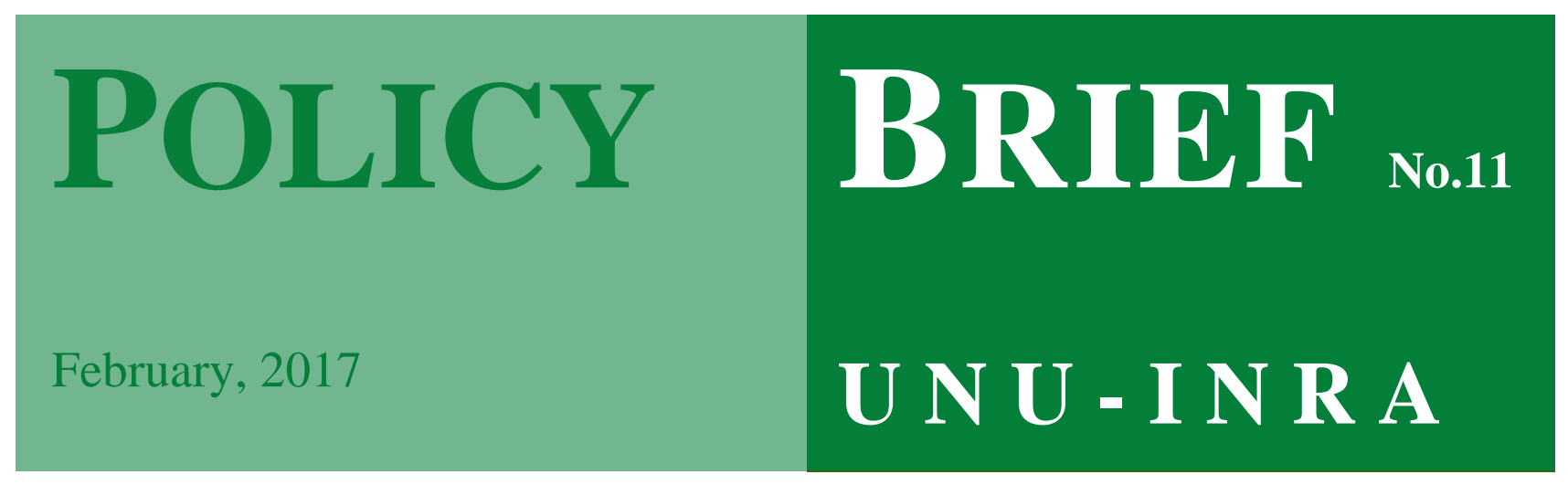

\title{
Reducing Crop Yield Volatility among Smallholder Farmers
}

By: James Atta Peprah, Clifford Afoakwah and Isaac Koomson

\section{EXECUTIVE SUMMARY}

This brief explores factors that influence crop yield volatility among rural and urban smallholder farmers in Ghana. The data was sourced from the sixth round of the Ghana Living Standard Survey (GLSS 6). The findings showed that while rural farmers in the forest and coastal zones experienced less volatility in their crop yield, rural farmers in the savannah belt experienced high volatility. The study revealed that smallholder farmers who had access to credit obtained 35.5 percent more yield per acre than their counterparts who did not have access to credit. Similarly, smallholder farmers who adopted farming technologies such as improved seeds and fertility-restoring technologies like organic manure, had about 65.7 percent more yield per acre than farmers who did not adopt any farming technology. To increase yield among smallholder farmers in Ghana, policy should focus on making credit available to farmers, especially those in the rural areas. Measures to enhance adoption of farming technologies such as organic manure, improved seeds, modern agricultural machinery and education of smallholder farmers on their use and importance, would help increase yield and reduce volatility.

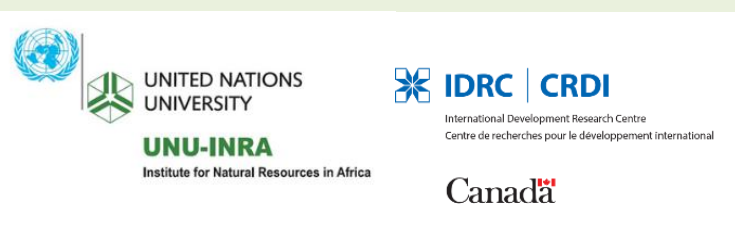

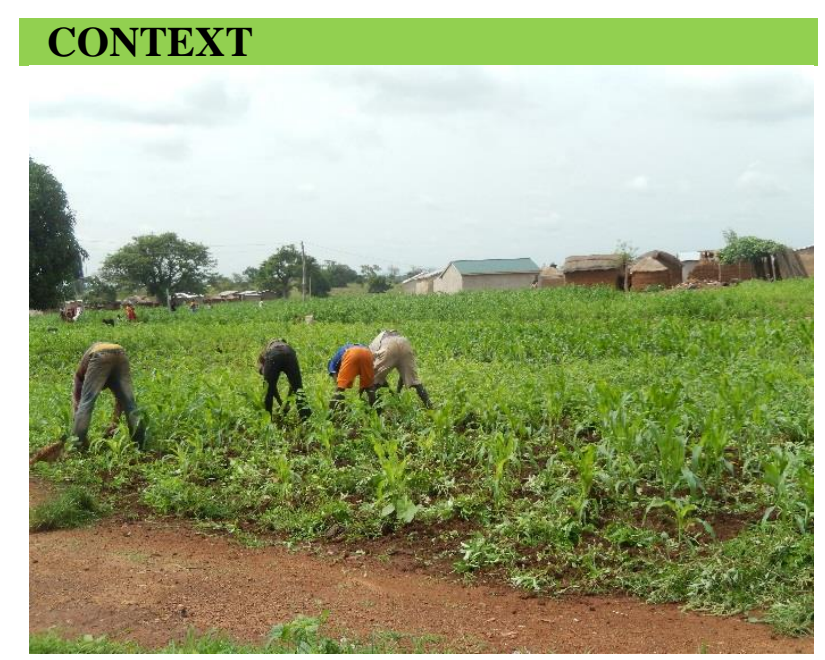

Smallholder farmers working in a farm. Photo: UNU-INRA

Agriculture in Ghana is mainly dominated by smallholder farmers. More than 70 percent of farmers in Ghana farm on three hectares (ha) of land or even smaller. Though these farms are small, they still play a vital role in the economy. In spite of the important role smallholder farmers play in the agriculture sector of the Ghanaian economy, these farmers usually lack access to credit. With the challenges in accessing credit, they are sometimes compelled to resort to using personal savings to finance their farming operations (Koomson et al., 2016). Due to the small nature of their farm sizes, financial institutions are unable to advance credit facilities to them. Farmers who want to purchase needed equipment and new technologies are therefore highly constrained due to small profits resulting from low yield. 


\section{CRITIQUE OF POLICY OPTIONS}

Currently smallholder farmers in Ghana do not benefit from credit and even if they do, it is very small. In most cases, credit in the form of cash is diverted for other purposes by the farmers, and does not go directly into agricultural production. Again, while input credit in the form of inorganic fertilizers and pesticides can increase yield, these do not promote green economy and smart agricultural practices. A more pragmatic way of making credit accessible should be in the form of promoting the use of organic inputs such as composts and animal by-products that add more value to the nutritional content of crops. This can contribute to better yield and at the same time promote green economy.

Smallholder farmers especially those in the rural areas also make limited use of technology. For instance, in Ghana, the current system of agricultural information dissemination mostly involves agricultural extension officers of the Ministry of Food and Agriculture, occasionally visiting farmers on their sites to educate them.

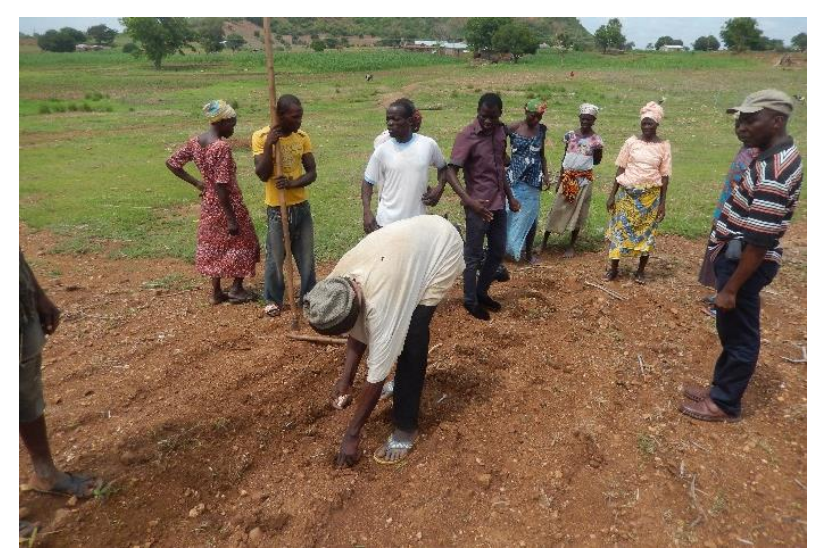

Agriculture Officers educating farmers. Photo: UNU-INRA

Efforts, such as this, may not fully equip smallholder farmers with the requisite knowledge on best practices, and on the use of technology.

\section{APPROACH}

This research employed Stochastic Dominance Analysis (SDA) to determine whether one can predict crop yield among rural farmers with higher levels of certainty compared to their urban counterparts or vice versa (using outcomes of crop yield volatility). Ordinary Least Squares (OLS) method was used to estimate the effect of credit and technology use on crop yield for the pooled model and rural-urban (sub-sampled) models, to cater for heterogeneity among rural and urban farmers.
The study examined the level of volatility in crop yield among rural and urban smallholder farmers and assessed the effect of access to credit and multiple inputs technology on crop yield per acre.

\section{KEY FINDINGS}

\section{Access to Credit and Crop Yield}

The findings showed that generally smallholder farmers that had access to credit obtained 35.5 percent more yield per acre than their counterparts that did not have access to credit. Rural farmers stand a chance of increasing their production by about $38.5 \%$ if they access credit. On the contrary, access to credit had no significant effect on yield among farmers in the urban areas.

In the urban areas, farming is normally not the primary occupation among households, hence farmers have to always sacrifice a significant part of their returns to invest in accessing credit for their farming activities. For the rural farmers, farming is seen as a primary economic activity, and so about $80.9 \%$ of farmers in this study are located in rural areas.

The findings demonstrate the significant role that credit plays in improving the yield of rural smallholder farmers. The results also back calls to make credit available to rural farmers to enable them increase their productivity.

\section{Technology and Crop Yield}

Adoption of technology also significantly improved the crop yield of smallholder farmers. Findings from the pooled model revealed that, generally smallholder farmers that adopted farming technology such as improved seeds and fertility-restoring technologies like organic manure, experienced about 65.7 percent more yield per acre than farmers who did not adopt any farming technology.

Among urban smallholder farmers, those who adopted farming technology such as improved seeds and fertility-restoring technologies like organic manure, had about 70.30 percent extra yield compared to farmers who did not adopt any technology. In the rural areas, farmers who adopted farming technology (improved seeds and organic manure) had more yield, about 61.90 percent, than their counterparts who did not adopt any technology in their farming operations. It can therefore be inferred that adopting technology is very beneficial in increasing yield. 
Table: Determinants of crop yield among smallholder farmers in Ghana (Three models used: pooled, urban and rural models)

\begin{tabular}{|c|c|c|c|}
\hline Log(crop yield per acre) & Pooled & Rural & Urban \\
\hline Explanatory variables & Coefficients & Coefficients & Coefficients \\
\hline \multicolumn{4}{|c|}{ Dummies for crop type harvested (Base= Industrial crop) } \\
\hline Cereals & $-0.868(0.083)^{* * *}$ & $-0.858(0.093) * * *$ & $-0.844(0.180)^{* * *}$ \\
\hline Legumes & $-0.790(0.150)^{* * *}$ & $-0.817(0.167)^{* * *}$ & $-0.243(0.340)$ \\
\hline Fruits & $-0.423(0.212)^{* *}$ & $-0.331(0.233)$ & $-0.699(0.479)$ \\
\hline Vegetables & $-0.740(0.980)$ & $-1.712(920)^{*}$ & $0.831(0.232)^{* * *}$ \\
\hline Other crops & $-0.904(0.357)^{* *}$ & $-0.682(0.38)^{*}$ & $-2.543(0.628)^{* * *}$ \\
\hline Credit & $0.355(0.102)^{* * *}$ & $0.385(0.119)^{* * *}$ & $0.155(0.186)$ \\
\hline Farm equipment use & $0.657(0.068)^{* * *}$ & $0.619(0.076)^{* * *}$ & $0.703(0.147)^{* * *}$ \\
\hline Land size & $-1.626(0.072)^{* * *}$ & $-1.702(0.079) * * *$ & $-1.274(0.161)^{* * *}$ \\
\hline Household size & $0.025(0.012)^{* *}$ & $0.037(0.014)^{* * *}$ & $-0.020(0.029)$ \\
\hline Male farmers & $0.019(0.016)$ & $0.013(0.017)$ & $0.098(0.046)^{* *}$ \\
\hline Female farmers & $0.057(0.012)^{* * *}$ & $0.063(0.013)^{* * *}$ & $0.021(0.023)$ \\
\hline Age & $0.029(0.013)^{* *}$ & $0.027(0.015)^{*}$ & $0.038(0.032)$ \\
\hline Age square & $0.0003(0.0001)^{* *}$ & $0.0002(0.0001)^{* *}$ & $-0.0005(0.0003)$ \\
\hline \multicolumn{4}{|c|}{ Land ownership (Base $=$ Rented $)$} \\
\hline Personal ownership & $-0.243(0.123)^{* *}$ & $-0.247(0.140)^{*}$ & $-0.197(0.251)$ \\
\hline Shared cropping & $-0.261(0.146)^{*}$ & $-0.272(0.164)^{*}$ & $-0.252(0.316)$ \\
\hline Rural & $-0.009(0.0818)$ & - & - \\
\hline Female & $-0.483(0.084)^{* * *}$ & $-0.466(0.096)^{* * *}$ & $-0.454(0.171)^{* * *}$ \\
\hline \multicolumn{4}{|c|}{$\underline{\underline{\text { Ecological zone }}(\text { Base }=\text { Coastal })}$} \\
\hline Forest & $0.274(0.154)^{*}$ & $0.315(0.165)^{*}$ & $0.510(0.443)$ \\
\hline Savannah & $0.577(0.159)^{* * *}$ & $0.463(0.172)^{* * *}$ & $1.347(0.425)^{* * * *}$ \\
\hline Constant & $6.739(0.425)^{* * *}$ & $6.729(0.421)^{* * *}$ & $-8.886(1.081)^{* * *}$ \\
\hline $\mathrm{N}$ & 4002 & 3234 & 768 \\
\hline Prob > chi 2 & $40.51 * * *$ & $36.88 * * *$ & $30.59 * * *$ \\
\hline $\mathrm{R}^{2}$ & 0.156 & 0.165 & 0.165 \\
\hline Chow test $(\mathrm{F}=2.186)$ & 0.0021 & & \\
\hline
\end{tabular}




\section{POLICY CONSIDERATIONS}

\section{Access to Credit}

Credit has been found to increase crop yield for rural smallholder farmers, and this may go a long way in reducing poverty. Therefore, existing agricultural policies should be strengthened to enhance smallholder farmers' access to credit. In this regard, measures should be put in place by financial institutions to ensure that funds given out for agriculture activities are not diverted for other purposes. Most importantly, policies should target reduction of the cost of credit for smallholder farmers, so as to promote access among rural farmers. When credit is made available, smallholder farmers can also acquire the needed technology that will increase their productivity.

Furthermore, creating an enabling environment that will encourage the setting up of rural banks and microfinance institutions in rural areas, will increase the stock of loanable funds

\section{REFERENCE}

Koomson, I., Annim, S.K. \& Peprah, J.A., 2016, "Loan refusal, household income and savings in Ghana: a dominance analysis approach", African Journal of Economics and Sustainable Development 5, 172-191. available to farmers. Access to credit can thus enable smallholder farmers adopt green agriculture practices such as the use of compost and other organic materials.

\section{Education and Training on use of Technology}

There is also the need for education and training on the use of technology among smallholder farmers. This can be supported by Agriculture Extension Officers. Farmers could be trained and advised to adopt yield-raising technologies such as improved seed varieties, and fertility-restoring and conservation technologies.

Additionally, the use of various media platforms such as community radio and television, mobile phone applications, community-based organisations, churches, and women groups for knowledge sharing on technology adoption and use, may also be beneficial.

\section{ACKNOWLEDGEMENT}

This work was carried out with the aid of a grant from the International Development Research Centre, Ottawa, Canada.

\section{精 IDRC $\mid$ CRDI}

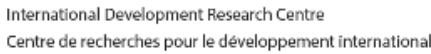

International Development Research Centre Centre de recherches pour le développement internationa

1 UNITED NATIONS

UNIVERSITY

\section{Canadằ}

\section{UNU-INRA}

Institute for Natural Resources in Africa

\section{ABOUT THE AUTHORS \\ James Atta Peprah is a Senior Lecturer and the Coordinator of the Microfinance Unit, Department of Economics, University of Cape Coast, Ghana. \\ Koomson Isaac is the Lead Economist at the Network for Socioeconomic Research and Advancement (NESRA), Ghana. \\ Clifford Afoakwah is a PhD Scholar at the School of Commerce, University of South Australia, Adelaide, Australia. \\ The Authors produced this policy brief as Home-Based Scholars of UNU-INRA.}

\section{This Policy Brief is prepared from a UNU-INRA Working Paper entitled:}

Crop Yield Volatility among Smallholder Farmers in Ghana

This policy brief and the working paper are available at collections.unu.edu

\section{CONTACT}

United Nations University Institute for Natural Resources in Africa (UNU-INRA)

Location: Second Floor, International House, Annie Jiagge Road, University of Ghana, Legon, Accra, Ghana

Address: PMB, KIA, Accra, Ghana

Tel: +233-302- 213850. Ext. 6318 Email: inra@unu.edu Website: www.inra.unu.edu @UNUINRA f @UNUINRA in United Nations University-INRA 